UC-11

Reporting Date: September 1974 Issued: October 1974

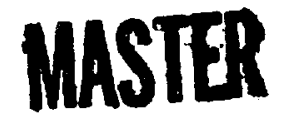

\section{Storm Runoff and Transport of Radionuclides in DP Canyon, Los Alamos County, New Mexico}

by

William D. Furtymun 


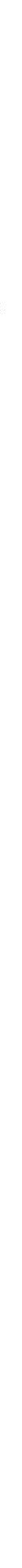

Printed in the United Stales al America. Available 1rom National Technical Information Service U.S. Deparment of Commerce

5285 Port Royal Road Springfield, Virginia 22151

Price: Printed Copy \$4.00 Microtiche \$1.45 
NOTICE

This tuport was prepared as an account of work sponsored by the Unitrd States Government. Neither the United States nor the United States Atomic Energy Co Thited Sians nor the Uniced Stales Alomic Energy Cammission, nor any of their employees, nor any of thei contractors, subcontractors, or the is employees, mikes any warknt, express or implied, or assumes any lesial tiability or responsibility for the accuracy, completeness or usefulness of any information, apparatus, product or protess disclosed, or represents that its use would not infringe privately awatd rights.

STORM RUNOFF AND TRANSPORT OF RADIONUCLIDES IN

DP CANYON, LOS ALAMOS COUNTY, NEW MEXICO

by

William D. Purtymun

\section{ABSTRACT}

Effluents from the waste treatment plant at Los Alamos Scientific Laboratory's Technical Area 21 are released into DP Canyon. The radionuclides remaning in the effluents are bound to stream-channel sediments which are later carried out of the canyon by storm runoff.

A study was made to determine the runoff volume, the suspended-sediment load, and the amount of radio. activity carried out of DP Canyon by storm runoff. During the summer of 1967 , precipitation resulted in 23 runoff events that carried $\approx 88000 \mathrm{~kg}$ ot suspended sediments out of the canyon in $\approx 36800 \mathrm{~m}^{3}$ of water. Less than $74 \mu \mathrm{Ci}$ of gross alpha emitter and $\approx 40100 \mu \mathrm{Ci}$ of gross beta were carried out of the canyon in solution. The suspended sediments carried out $\approx 70 \mu \mathrm{Ci}$ of gross alpha emitters and $\approx 11300 \mu \mathrm{Ci}$ of gross beta emitters. About 31000 $\mu C i$ of ${ }^{\circ} \mathrm{Sr}$ left the canyon in solution, as did traces of ${ }^{238} \mathrm{Pu}, 2 ? 9 \mathrm{Pu}$, and ${ }^{241} \mathrm{Am}$.

\section{INTRODUCTION}

Certain liquid wastes produced by the Los Alamos Scientific Laboratory contain small amounts of radioactivity. These wastes are treated chemically and by ion exchange to reduce the radioactivity before the effluents are released into canyons adjacent to the treatment plants. As the effluents move down the canyons in the intermittent flow in the strean channels, any remaining radioactivity is bound to the bed sediments, thereby reducing the anounts of radioactivity in surface flow and shallow ground water in the alluvium.

In DP Canyon, which will be discussed here, the radioactivity concentrations in the bed sediments decrease downgradient from the point of effluent outfall. Radioactivity does not build up in the sediments at the outfall because the radionuclides and sediments are dispersed and carried down :he canyon by storm runoff. 1

The purpose of the present study was to estimate the amount of radioactivity transported by storm runoff from DP Canyon, which receives low-level radioactive effluents from Technical Area 21 (TA-21). The report is based on data collected in the canyon during the summer of 1967.

TA-21 is located on a small mesa that is part of the Pajarito Plateau. Effluents are released into DP Canyon north of the technical area (Fig. 1). The stream in the canyon is intermittent and arises from lowlevel radioactive industrial effluents, 


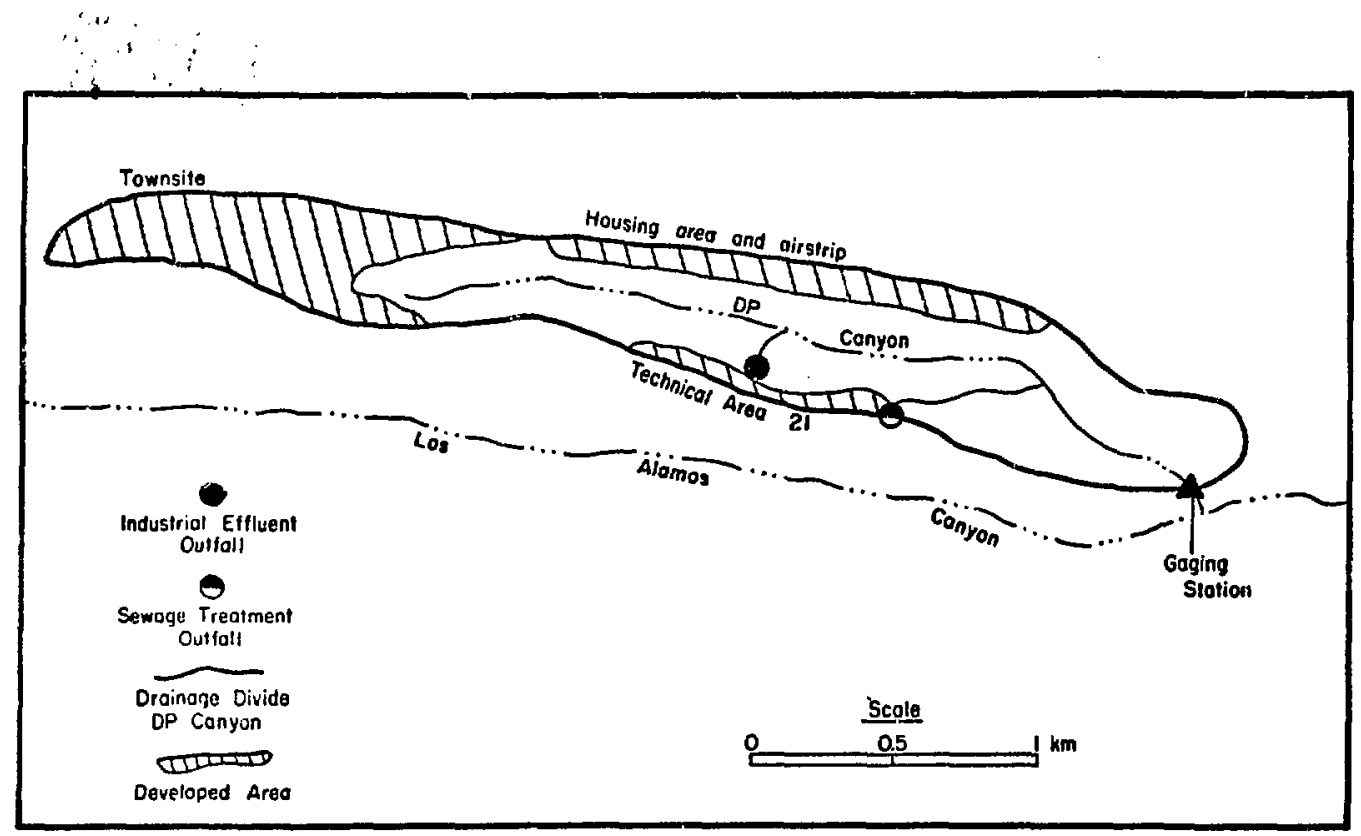

Fig. 1. Drainage area of DP Canyon, showing effluent outfalls and gaging station.

sewage effluents, and occasional storm runoff.

DP Canyon enters Los Alamos Canyon near the center of the Plateau. Strean flow in Los Alamos Canyon also is intermittent and is dependent on storm runoff. The canyon is tributary to the Rio Grande which is $11.2 \mathrm{~km}$ to the east.

The amount of suspended sediments and volume of storm runoff in DP Canyon were determined at a gaging station at the mouth of the canyon. Radiochemical analyses were made of the suspended sediments and the solution in the runoff.

The TA-21 waste treatment plant releases $\approx 950 \mathrm{~m}^{3}$ of effluent per month into DP Canyon in $\approx 75-\mathrm{m}^{3}$ "slugs." The main radionuslides in the effluent during the summer of 1967 were plutonium, americium, and strontium. Mixed fission products were presert is minor amounts. The sewage treatment plant releases $\approx 1900 \mathrm{~m}^{3}$ of effluent per month into the lower part of the canyon (Fig. 1). The release of sewage effluents is continuous, but the discharge is s1ightly greaier during the working day. The industrial and sewage effluents flow eastward down the canyon, moving into the thin alluvium in the mid-reaches of the canyon. The major area of surface water loss is in the lower part of the canyon where the alluvium thickens and is underlain by a nonwelded tuff.

I I THANNEL CHARACTERISTICS

DP Canyon heads on the Pajarito Plateau and is 2.4-km long (above its junction with Los Alamos Canyon). Its drainage area is $\approx 1.6 \mathrm{~km}^{2}$, of which $\approx 0.5 \mathrm{~km}^{2}$ lies in a developed area (roads, buildings, parking areas, and part of an airstrip). The upper $1.6 \mathrm{~km}$ of the canyon is cut into nonwelded and moderately welded units of the Tshirege Member of the Bandelier Tuff. ${ }^{2}$ The channel gradient here is $\approx 19 \mathrm{~m} / \mathrm{km}$. Grasses and small shrubs grow along the banks. The channel contains a thin section of sands and gravels, with occasional exposure of tuff.

The lower $0.8 \mathrm{~km}$ of the canyon is deep and narrow, cut through a welded unit of tuff underlain by a nonwelded unit of tuff. The channel fills the narrow canyon floor and is strewn with large boulders and blocks of tuff dislodged from the canyon walls. 
The gradient ir this section is $\approx 144 \mathrm{~m} / \mathrm{km}$, and there are numerous waterfalls, the largest having a drop of $6 \mathrm{~m}$. The channel is composed of sands and boulders, and the alluvium thickens to $\approx 5.5 \mathrm{~m}$ at the junction with Los Alamos Canyon.

The cobbles and boulders in the canyon's stream channel are mainly of latite and rhyolite that were inclusions in the ashflows. Numerous, also, are cobbles and boulders of the more welded types of tuff. The cobbles and boulders are in a matrix of sand and gravel. Silt-clay and very fine sand-size fractions make up $>50 \%$ by weight of the tuff weathered in place and $>50^{\circ}$ of the suspended sediments, whereas the sediments in the stream channel contain $\approx 2 \%$ of that size fraction (Table I). The finer material is sifted out of the channel sediments and is transported out of the canyon by storm runoff.

The silt and clay are largely montmorillonite and illite which are weathering products of the tuff. ${ }^{3}$ Montmorillonite and illite have medium ion-exchange capacities in river sediments in the United States. 4 These clay minerals are believed to be responsible for the effectiveness of the Los Alamos soil in removing plutonium from waste solutions. 3

Sediments in the sand-size class, $0.062-$ to 2 -mm-diam, are largely quartz and sanidine crystals and crystal fragments. Also present are small amounts of rock fragments of tuff, pumice, rhyolite, latite, and some mafic minerals. Sediments in the very fine gravelsize class, 2- to 4-mm-diam, are large $1 y$ tuff, pumice, latite, and rhyolite rock fragments. The large particle-size material in the stream channel also takes up some of the radionuclides, perhaps because of the presence of clay coating on the crystals or rock fragments.

\section{I. STORM RUNOFF}

A gaging station (Fig. 1) with a continuous water-stage recorder was constructed at the mouth of DP Canyon in May 1967 to permit measurement of storm runoff from the canyon. The control was a $91-\mathrm{cm}$ rectangular weir. A stage-discharge rating curve was determined by current-meter and dye-dilution measurements.

Precipitation over the area resulted in 23 runoff events in DP Canyon from May through September 1967. The duration of flow, mean discharge, and volume of flow are given in Table II. The mean discharge rangea from 6-11? $\ell$ /s, while runoff ranged from 80$9000 \mathrm{~m}^{3}$. ist.al runoff for the period was $\approx 36800^{\circ} \mathrm{m}^{3}$.

\section{IEDIMENT TRANSPORT}

Soils in the DP Canyron drainage area firs derived from weathering of tuff. Overland runoff moves loose, erodible particles from the land surface into the stream channel. Once in the channel, these sediment particles are transported b: itream flow either in suspension or in solution.

only the suspended sediments are considered here in the transport of radionuclides. These sediments are classified as having a mean diameter $<6 \mathrm{~mm}(6 \mathrm{~mm}$ is the intake size of the DH-48 sampler, and the single-stage and cumulative samplers used in the study).

Single-stage samplers were installed at the gaging station 8 and $38 \mathrm{~cm}$ above the crest of the weir to collect suspended-sediment samples during the initial part of each runoff event. 5 A DH-48 sampler was used to collect additional sediment samples from the flow during both the initial part and the tailoff of the event. Sediment concentrations were then determined. A sediment-concentration graph was constructed from these data and served as a basis for estimating suspended-sediment concentrations. For each flow event the sediment concentrations were integrated with volume of discharge. The mean suspended sediment concentration and total suspended-sediment load for each flow event are shown in Table II, along with the duration of flow, the mean discharge, and volume. 
The largest susfended-sediment load to pass the gaging station in a single event was $29000 \mathrm{~kg}$ in a total flow volume of $8410 \mathrm{~m}^{3}$ on August 10, when the weather station recorded $2 \mathrm{~cm}$ of precipitation in a $6-\mathrm{h}$ period. A maximum discharge of $1190 \mathrm{l} / \mathrm{s}$ occurred in the second hour of the event and had an estimated mean suspended-sediment concentration of $\approx 28600 \mathrm{mg} / \ell$.

The second largest suspended-sediment load was $22000 \mathrm{~kg}$ in a total flow volume of $9000 \mathrm{~m}^{3}$ ruring July 16-18. Precipitation for a 17-h period on July 16 and 17 was 4.5 $\mathrm{cm}$. The maximum discharge was $680 \mathrm{l} / \mathrm{s}$ during the third hour of the event and the mean sediment concentration was $21400 \mathrm{mg} / \ell$.

One of the smaller runoff events occurred between 0200 and 1300 on August 11, when $400 \mathrm{~m}^{3}$ of flow transported $\approx 200 \mathrm{~kg}$ of suspended sediment. Precipitation for the period was $1.2 \mathrm{~cm}$. The maximum discharge of $\approx 25 \mathrm{l} / \mathrm{s}$ was reached in the first hour and had a mean suspended-sediment concentration of $6000 \mathrm{mg} / \ell$. The stresm channel and underlying tuff were saturated by previous runoff which had occurred almost daily since July 30. Runoff from the second hour until the conclusion of the event was from bank storage, sewage effluent, and release of industrial effluent.

The storm runoff of $36800 \mathrm{~m}^{3}$ that occurred during the 5 -month period of study carried $\approx 88000 \mathrm{~kg}$ of suspenc.d sediment past the gaging station.

\section{RADIOACTIVITY IN STORM RUNOFF}

Cumulative samplers (plastic bottles with 6-mm-diam intake) were used to collect samples of water-sediment mixtures during 9 of the 23 runoff events. The intakes, de. signed to reduce the velocity of flow into the sampler, were placed at the crest of the weir and at 30 and $61 \mathrm{~cm}$ above the crest. The water-sediment mixtures were prepared for analysis by allowing the suspended sediments to settle out, then decanting the clear portion and filtering to remove any sediment remaining in suspension. Chemical and radiochemical analyses were made of the solution. The amount of suspended sediments was so limited that only gross alpha and beta determinations could be made. Results for sediments were above the natural background of 1.4 and $1.2 \mathrm{pCi} / \mathrm{g}$ for gross alpha and beta concentrations, respectively, found in adjacent canyons that do not receive industrial effluents.

A. Radioactivity in Solution

Chemical analyses were made for select

ions (Table III). The ion concentrations were slightly higher than expected. The effluents may have evaporated during dry periods, with consequent concentration and precipitation of some of the ions into the channel sediments. Storm runoff would redissolve the precipitates, resulting in ion concentrations slightly higher than normal. The basic $(\mathrm{pH}>7.0)$ runoff would facilitate ion exchange and adsorption of most radionuclides by the silt- and clay-size fraction of the sediments. 6

Gross alpha emitters in solution were $<2$ pCi/l; gross beta emitters ranged from 520-2180 pCi/l. Traces of ${ }^{230} \mathrm{Pu},{ }^{239} \mathrm{Pu}$, and ${ }^{241} \mathrm{Am}$ were found in solution (Table IV). The presence of considerable amounts of ${ }^{90} \mathrm{Sr}$ may account for the high gross beta. Radium-226 and ${ }^{237} \mathrm{Cs}$ were below the respective 1 imits of detection of 0.15 and $240 \mathrm{pCi} / \ell$.

Table $V$ shows the variational trends in gross beta and strontium concentrations during the summer. There was no variational trend for plutonium and americium concentrations from one runoff event to the next. B. Radioactivity in Suspended Sediments The uptake of radionuclides from solution by channel sediments is the rule rather than the exception. 7 The silt-and clay-size fraction of sediment has the greatest capacity for ion exchange and adsorption of radionuclides. This capacity decreases with increasing particle size. In the stream channel, sand and gravel make up the bulk of the sediments and there are only small amounts of silt and clay. However, in the storm runoff the suspended sediments are composed 
mainly of the silt- and clay-size fraction, and thus there is a greater capacity for adsorption and transport of radionuclide than with sand and gravel. There was no variational trend in gross alpha from one event to another, whereas the gross beta emitters exhibited a trend (Table VI) similar to that found when they were in solution (Table V).

VI. TRANSPORT OF RADIONUCLIDES Radiochemical analyses were made of runoff samples (solution and suspended sediments c collected from 9 of the 23 runoff events. On the basis of the average concenurations of these samples, an estimaze was mace of the total amount of gross alpha and gross beta emitters carried from the canyon (Table VII).

The gross alpha emitters were transported in solution and with the suspended sediments. Less than $74 \mu \mathrm{Ci}$ was carried out in soiurion and an estimated $70 \mu \mathrm{Ci}$ were rransported with suspended sediments.

The gross beta emitters also were present in solution and in the suspended sediments. An estimated $40100 \mu \mathrm{Cj}$ were carried out of the canyon in solution and $\approx 11300$ $\mu \mathrm{Ci}$ were carried out with suspended sediments.

An estimated $31000 \mu \mathrm{Ci}$ of ${ }^{90} \mathrm{Sr}$ left the canyon in solution. The amounts of ${ }^{23}{ }^{8} \mathrm{Pu}$, ${ }^{2}{ }^{9} \mathrm{Pu}$, and ${ }^{241} \mathrm{Am}$ transported in solution were estimated at $5.9,7.0$, and $9.2 \mu \mathrm{Ci}$, respectively.

\section{REFERENCES}

1. W. D. Purtymun, G. L. Johnson, and E. C. John, "Distribution of Radioactivity in the Alluvium of a Disposal Area at Los Alamos, New Mexico," U,S. Geo1. Survey Prof. Paper 550-D (1966).

2. R. L. Griggs, "Geology and Groundwater Resources of the Los Alamos Area,"U.S. Geol. Survey Water-Supply Paper 1753 (1964).

3. E. Staritzky, "Report on Petrographic Examination of Local Soils," Los Alamos Scientific Laboratory report LA-741 (1949).

4. V. C. Kennedy, "Mineralogy and CationExchange Capacity of Sediments from Selected Streams,"U.S. Geo1. Survey Prof. Paper 433-D (1965).

5. U.S. Inter-Agency Committee on Water Resources, "Determination of Fluvial Sediment Discharge," U.S. Govt. Printing Off., Washington, DC. (1963).

6. J. S. Hosking, "The Cation-Exchange $\mathrm{Ca}-$ pacity of Soils and Soil Colloids," Council for Sci. and Ind. Res. J. U21 (1948).

7. W. W. Sayre, H. P. Guy, and A. R. Chamberlain, "Uptake and Transport of Radionuclides by Stream Sediments," U.S. Geo1. Survey Prof. Paper 433-A (1964). 
TABLE I

AVERAGE PARTICLE-SIZE DISTRIBUTION OF WEATHERED TUFF, CHANNEL AND SUSPENDED SEDIMENTS ${ }^{a}$

\begin{tabular}{|c|c|c|c|c|}
\hline Classification & $\begin{array}{c}\text { Particie } \\
\text { Diameter } \\
\text { (mm) } \\
\end{array}$ & $\begin{array}{l}\text { Weathered } \\
\text { Tuff } \\
(8) \\
\end{array}$ & $\begin{array}{l}\text { Channel } \\
\text { Sed iment } \\
\text { (8) }\end{array}$ & $\begin{array}{l}\text { Suspended } \\
\text { Sediment } \\
\text { (8) }\end{array}$ \\
\hline Silt and clay & $<0.062$ & 42 & 1.5 & 35 \\
\hline Very fine sand & $0.062-0.125$ & 9 & 0.5 & 17 \\
\hline Fine sand & $0.125-0.250$ & 10 & 5 & 15 \\
\hline Medium sand & $0.250-0.500$ & 12 & 12 & 13 \\
\hline Coarse sand & $0.500-1.00$ & 16 & 39 & 14 \\
\hline Very coarse sand & $1.00-2.00$ & 10 & 37 & 6 \\
\hline Very fine gravel & -4.00 & 1 & 5 & 0 \\
\hline
\end{tabular}

average of five analyses. 
TABLE II

DISCHARGE CHARACTERISTICS FOR 23 RUNOFF EVENTS IN DP CANYON

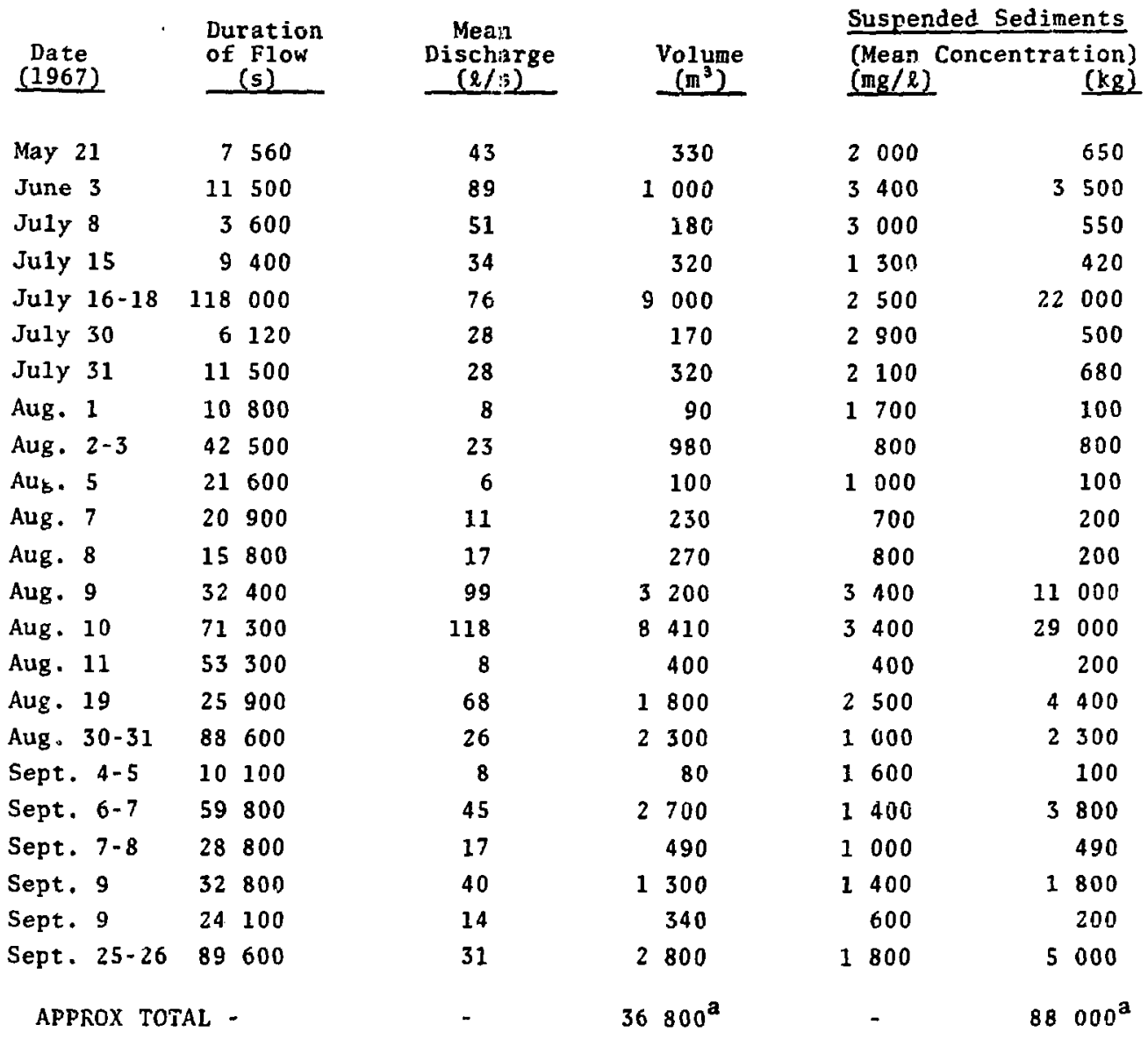

$\overline{a_{\text {Rounded off to three significant figures }}}$

TABLE III

CHEMICAL ANALYSIS OF SOLUTION IN STORM RUNOFF

\begin{tabular}{|c|c|c|c|c|}
\hline \multirow[b]{2}{*}{ Determination } & \multirow[b]{2}{*}{ Units } & \multicolumn{3}{|c|}{ Range ${ }^{a}$} \\
\hline & & $\begin{array}{c}\text { Min } \\
(\mathrm{pCi} / \ell) \\
\end{array}$ & $\begin{array}{c}\operatorname{Max} \\
(p C i / l) \\
\end{array}$ & $\begin{array}{c}\mathrm{Av} \\
(\mathrm{pCi} / 2)\end{array}$ \\
\hline Chloride & $\mathrm{mg} / \mathrm{l}$ & 15 & 50 & 36 \\
\hline Fluoride & $\mathrm{mg} / \mathrm{l}$ & 2 & 7 & 4 \\
\hline Nitrate & $\mathrm{mg} / \mathrm{l}$ & 0.3 & 2.0 & 0.9 \\
\hline Dissolved solids & $\mathrm{mg} / \mathrm{l}$ & 221 & 518 & 304 \\
\hline Conductivity & umho/cm & 270 & 680 & 405 \\
\hline $\mathrm{pH}$ & - & 7.8 & 9.2 & 8.4 \\
\hline
\end{tabular}


IN-SOLUTION RADIOACTIVITY IN STORM RUNOFF

\section{Determination}

Gross alpha

Gross beta

Plutonium-238

Plutonium-239

Americium-241

Strontium-90

Nine analyses.
Range $e^{a}$

$\frac{\text { Range }^{a}}{\operatorname{Min}_{(\mathrm{pC} i / \ell)}} \underset{\substack{\operatorname{Max} \\(\mathrm{pC} i / \ell)}}{\substack{\mathrm{Av} \\(\mathrm{pC} i / \ell)}}$

$<2$

520

$2180 \quad 1090$

$<0.05$

0.25

0.16

0.08

0.27

0.19

$<0.05$

1.07

0.25

360

2160

850
TABLE $\mathrm{V}$

GROSS BETA AND STRONTIUM-90 IN RUNOFF SOLUTION

\begin{tabular}{lc}
$\begin{array}{c}\text { Date } \\
(1967)\end{array}$ & $\begin{array}{c}\text { Gross Beta } \\
(\mathrm{pCi} / \ell)\end{array}$ \\
\cline { 2 - 2 } July 9 & 2180 \\
July 16 & 1230 \\
Aug. 1 & 1180 \\
Alg. 2 & 915 \\
Aug. 7 & 525 \\
Aug. 9 & 1080 \\
Aug. 11 & 870 \\
Aug. 19 & 520 \\
Sept. 9 & 1070
\end{tabular}

\begin{tabular}{c}
$\begin{array}{c}\text { Strontium }-90 \\
(\mathrm{pCi} / \ell)\end{array}$ \\
\hline 2160 \\
905 \\
920 \\
725 \\
360 \\
745 \\
685 \\
365 \\
800
\end{tabular}

TABLE VI

GROSS ALPHA AND BETA IN SUSPENDED SEDIMENTS OF RUNOFF

\begin{tabular}{|c|c|c|}
\hline $\begin{array}{c}\text { Date } \\
(1967) \\
\end{array}$ & $\begin{array}{l}\text { Gross Alpha } \\
(\mathrm{pCi} / \mathrm{g}) \\
\end{array}$ & $\begin{array}{l}\text { Gross Beta } \\
(\mathrm{pCi} / \mathrm{g}) \\
\end{array}$ \\
\hline July 8 & 0.7 & 249 \\
\hline Ju1y 15 & 0.9 & 172 \\
\hline July 18 & 1.0 & 119 \\
\hline July 31 & 0.3 & 111 \\
\hline Aug. 3 & 0.8 & 92 \\
\hline Aug. 7 & 1.2 & 133 \\
\hline Aug. 9 & 1.1 & 139 \\
\hline Aug. 11 & 0.4 & 95 \\
\hline Aug. 19 & 0.6 & 42 \\
\hline AVERAGE & 0.8 & 1.28 \\
\hline
\end{tabular}


TABLE VII

AMOUNT OF RADIONUCLIDES TRANSPORTED

IN STORM RUNOFF

In Solution

Gross alpha

Gross beta

Plutonium-238

Plutonium-235

Americium-241

Strontitu-90

In Suspended Sediments

Gross alpha

Gross beta
Estinated

Microcuries

$<74$

$40 \quad 100$

5.9

7.0

9.2

31000

70

11300

HK:436(210) 